\title{
Kribbella ginsengisoli sp. nov., isolated from soil of a ginseng field
}

\author{
Ying-Shun Cui, ${ }^{1}$ Jung-Sook Lee, ${ }^{2}$ Sung-Taik Lee ${ }^{1}$ and Wan-Taek $\mathrm{Im}^{1}$ \\ ${ }^{1}$ Department of Biological Sciences, Korea Advanced Institute of Science and Technology, 373-1, \\ Guseong-dong, Yuseong-gu, Daejeon 305-701, Republic of Korea \\ ${ }^{2}$ Korean Collection for Type Cultures (KCTC), Korea Research Institute of Bioscience and \\ Biotechnology, 52 Oeundong, Yusong-gu, Daejeon 305-333, Republic of Korea
}

Correspondence

Wan-Taek Im

wandra@kaist.ac.kr

Sung-Taik Lee

e_stlee@kaist.ac.kr
The genus Kribbella was established by Park et al. (1999) as a result of the reclassification of two strains, 'Nocardioides fulvus' IFO 14399 and Nocardioides sp. ATCC 39419, as the type strains of Kribbella flavida and Kribbella sandramycini, respectively. At the time of writing, the genus included a further 11 species: Kribbella koreensis (Sohn et al., 2003), K. antibiotica (Li et al., 2004), K. lupini (Trujillo et al., 2006), K. solani (Song et al., 2004), K. jejuensis (Song et al., 2004), K. yunnanensis (Li et al., 2006), K. alba (Li et al., 2006), K. karoonensis (Kirby et al., 2006), K. swartbergensis (Kirby et al., 2006), K. aluminosa (Carlsohn et al., 2007) and K. hippodromi (Everest \& Meyers, 2008). In this study, we report on the taxonomic characterization of a novel Kribbella strain, Gsoil $001^{\mathrm{T}}$.

Strain Gsoil $001^{\mathrm{T}}$ was isolated from the soil of a ginseng field in Pocheon Province, South Korea. The soil sample was thoroughly suspended and serially diluted in $50 \mathrm{mM}$ phosphate buffer ( $\mathrm{pH}$ 7.0) and spread on one-fifthstrength modified-R2A agar plates (Cui et al., 2007).

The GenBank/EMBL/DDBJ accession number for the 16S rRNA gene sequence of strain Gsoil $001^{\top}$ is AB245391.

Supplementary tables showing the characteristics that differentiate strain Gsoil $001^{\top}$ from K. koreensis KACC $20250^{\top}$ and detailed DNADNA hybridization results are available with the online version of this paper.
Strain Gsoil $001^{\mathrm{T}}$ was isolated after incubation at $30{ }^{\circ} \mathrm{C}$ for 1 month. The strain was subsequently cultured on R2A agar (Difco) at $30{ }^{\circ} \mathrm{C}$ and maintained as a glycerol suspension $\left(20 \%\right.$, w/v) at $-70{ }^{\circ} \mathrm{C}$.

Gram-reaction testing was performed by the non-staining method as described by Buck (1982). Cell morphology was observed at $\times 1000$ magnification with a light microscope (Nikon) using cells grown for $24 \mathrm{~h}$ at $30{ }^{\circ} \mathrm{C}$ on modified R2A agar. Catalase activity was determined by bubble production in $3 \%(\mathrm{v} / \mathrm{v}) \mathrm{H}_{2} \mathrm{O}_{2}$ and oxidase activity was determined using $1 \%(\mathrm{w} / \mathrm{v})$ tetramethyl $p$-phenylenediamine. For studies on sole-carbon-source utilization, we performed the 96-well-tray method (Cui et al., 2007). Some physiological characteristics were determined with API 20E, API 20NE and API ID32 GN galleries (bioMérieux), according to the manufacturer's instructions. Aerobic nitrate reduction was confirmed in three $25 \mathrm{ml}$ serum bottles containing $12 \mathrm{ml} \mathrm{R} 2 \mathrm{~A}$ broth supplemented with $10 \mathrm{mM} \mathrm{KNO}_{3}$. The reduction of nitrate was monitored by an ion chromatograph (model 790 personal IC; Metrohm) equipped with a conductivity detector and an anion-exchange column (Metrosep Anion Supp 4; Metrohm). Tests for the degradation of DNA [by flooding DNase agar (Scharlau) plates with $1 \mathrm{M} \mathrm{HCl}$, casein, chitin, starch (Atlas 1993), lipid (Kouker \& Jaeger, 1987), xylan 
and cellulose (Ten et al., 2004) were evaluated after 10 days. Growth at 4, 6, 8, 10, 12, 15, 20, 25, 30, 37, 42 and $45{ }^{\circ} \mathrm{C}$ and $\mathrm{pH} 5.0-10.0$ (at intervals of $0.5 \mathrm{pH}$ units) was assessed after 5 days of incubation. Salt tolerance was tested on modified R2A agar supplemented with 1-10\% $(\mathrm{w} / \mathrm{v}) \mathrm{NaCl}$ after 5 days of incubation. Growth on nutrient agar, trypticase soy agar and MacConkey agar was also evaluated at $30{ }^{\circ} \mathrm{C}$. Sensitivity to antibiotics was tested on R2A agar using discs containing the following $(\mu \mathrm{g})$ : streptomycin sulfate $(2,4,6$ and 12), gentamicin sulfate $(2,4,6$ and 12), tetracycline hydrochloride $(4.5,7.2,10$ and $15)$, chloramphenicol $(5,10,15$ and 30), kanamycin $(2,4,6$ and 12$)$, penicillin $(6,12,18$ and 24$)$ and erythromycin (2, 4,6 and 9).

Extraction of genomic DNA was performed with a commercial genomic DNA extraction kit (Solgent) and PCR-mediated amplification of the 16S rRNA gene and sequencing of the purified PCR product were carried out according to Ten et al. (2008). An almost-complete sequence was compiled using SeqMan software (DNASTAR). The 16S rRNA gene sequences of related taxa were obtained from the GenBank database. Multiple alignments were performed with CLUSTAL X (Thompson et al., 1997). Gaps were edited in the BioEdit program (Hall, 1999). Evolutionary distances were calculated using Kimura's two-parameter model (Kimura, 1983). Phylogenetic trees were constructed by using neighbourjoining (Saitou \& Nei, 1987) and maximum-parsimony (Fitch, 1971) methods with the MEGA3 program (Kumar et al., 2004) and bootstrap values were calculated on the basis of 1000 replications (Felsenstein, 1985).

For the measurement of chromosomal DNA $\mathrm{G}+\mathrm{C}$ content, genomic DNA of the novel strain was extracted and purified as described by Moore \& Dowhan (1995) and the $\mathrm{G}+\mathrm{C}$ content was determined as described by Mesbah et al. (1989) using reversed-phase HPLC. Cellular fatty acid profiles were determined for strains grown on trypticase soy broth (TSB; Difco) for 5 days. The cellular fatty acids were saponified, methylated and extracted according to the protocol of the Sherlock Microbial Identification System (MIDI). The fatty acids were analysed with a gas chromatograph (Hewlett Packard 6890) and identified by the Microbial Identification software package (Sasser, 1990). For chemotaxonomic analysis (isoprenoid quinones, cell-wall peptidoglycan types, polar lipids and cell-wall sugars), strain Gsoil $001^{\mathrm{T}}$ was grown in modified R2A broth for 7 days at $30{ }^{\circ} \mathrm{C}$. Collected cells were lyophilized for $24 \mathrm{~h}$. Isoprenoid quinones were extracted with chloroform/methanol $(2: 1, \mathrm{v} / \mathrm{v})$, evaporated under vacuum conditions and re-extracted in $\mathrm{n}$-hexane/water $(1: 1, \mathrm{v} / \mathrm{v})$. The crude $\mathrm{n}$-hexane-quinone solution was purified using Sep-Pak Vac silica cartridges (Waters) and subsequently analysed by HPLC as described by Hiraishi et al. (1996). The cell-wall peptidoglycan was determined by using TLC after hydrolysis with $6 \mathrm{M} \mathrm{HCl}$ at $100{ }^{\circ} \mathrm{C}$ for 18 h, as described by Komagata \& Suzuki (1987). Polar lipids were extracted, examined by two-dimensional TLC and identified as described by Minnikin et al. (1977). Cellwall sugars were analysed as described by Staneck \& Roberts (1974).

The 16S rRNA gene sequence of strain Gsoil $001^{\mathrm{T}}$ determined in this study was a continuous stretch of $1482 \mathrm{nt}$ (base positions 9-1512 with respect to the Escherichia coli numbering system). Sequence similarity calculations after a neighbour-joining analysis indicated that the closest relatives of strain Gsoil $001^{\mathrm{T}}$ were K. koreensis $\mathrm{LM}$ $161^{\mathrm{T}}\left(99.0 \%\right.$ similarity), K. flavida KACC $20248^{\mathrm{T}}(98.8 \%)$, K. alba YIM $31075^{\mathrm{T}}(98.8 \%)$, K. sandramycini ATCC $39419^{\mathrm{T}}(98.4 \%)$, K. karoonensis $\mathrm{Q}^{\mathrm{T}} \mathrm{T}^{\mathrm{T}}(98.4 \%)$, K. antibiotica YIM $31530^{\mathrm{T}}(98.3 \%)$, K. yunnanensis YIM $30006^{\mathrm{T}}$ (98.2\%), K. swartbergensis HMC25 ${ }^{\mathrm{T}}(98.2 \%)$, K. lupini $\mathrm{LU}_{14}^{\mathrm{T}}(97.9 \%)$, K. hippodromi S1.4 ${ }^{\mathrm{T}}(97.8 \%)$, K. aluminosa HKI $0478^{\mathrm{T}}(97.7 \%), K$. solani $\mathrm{DSAl}^{\mathrm{T}}(97.4 \%)$ and $K$. jejuensis HD9 $^{\mathrm{T}}(96.9 \%)$. Lower sequence similarities $(<94.1 \%)$ were found with all other recognized species of the family Nocardioidaceae. This relationship between strain Gsoil $001^{\mathrm{T}}$ and other members of the genus Kribbella was also evident in the phylogenetic tree, which used over $1300 \mathrm{nt}$ (Fig. 1). Strain Gsoil $001^{\mathrm{T}}$ and 13 recognized species of genus Kribbella formed a monophyletic clade with a high bootstrap value (100\%), which was supported by both treemaking methods employed in this study.

The results of the morphological and physiological characterization are given in the species description and in Table 1. Comparison of some physiological characteristics of strain Gsoil $001^{\mathrm{T}}$ with those of related type strains are also shown in Table 1 and, for K. koreensis KACC $20250^{\mathrm{T}}$, in Supplementary Table S1 (available in IJSEM Online). Strain Gsoil $001^{\mathrm{T}}$ could be differentiated easily from K. koreensis KACC $20250^{\mathrm{T}}$ on the basis of solecarbon-source utilization patterns.

DNA-DNA hybridization experiments were performed between strain Gsoil $001^{\mathrm{T}}$ and type strains of the genus Kribbella with the method described by Ezaki et al. (1989) using photobiotin-labelled DNA probes and micro-dilution wells. Hybridization was performed with five replications for each sample. The highest and lowest values obtained for each sample were excluded and the means of the remaining three values were converted to percentage DNA-DNA relatedness values. DNA-DNA relatedness values between strain Gsoil $001^{\mathrm{T}}$ and the type strains of the 13 Kribbella species were in the range 5-45\% (K. koreensis, 45\%; K. flavida, 22\%; K. alba, $24 \%$; K. sandramycini, $22 \%$; K. karoonensis, $12 \%$; K. antibiotica, $24 \%$; K. yunnanensis, $17 \%$; K. swartbergensis, $10 \%$; K. lupini, $18 \%$; K. hippodromi, $18 \%$; K. aluminosa, $20 \%$; K. solani, $11 \%$; K. jejuensis, $5 \%$ ). Detailed results of the DNA-DNA relatedness analysis are shown in Supplementary Table S2. These values are low enough to assign strain Gsoil $001^{\mathrm{T}}$ to a novel species of genus Kribbella (Wayne et al., 1987).

Results of chemotaxonomic analyses are given in the species description. The respiratory quinone system of 


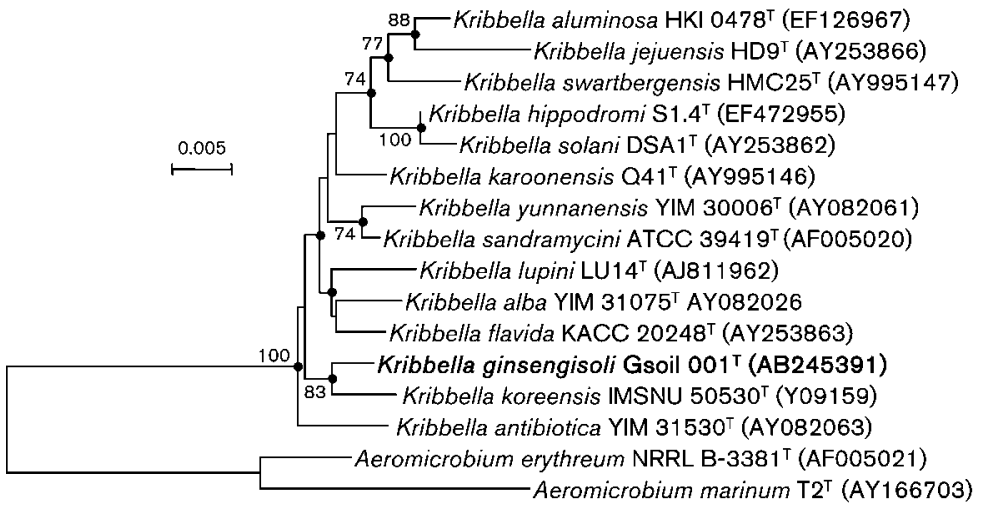

Fig. 1. Neighbour-joining phylogenetic tree constructed from a comparative analysis of 16S rRNA gene sequences showing the relationships of strain Gsoil $001^{\top}$ (Kribbella ginsengisoli sp. nov.) with other related species. Filled circles indicate that the corresponding nodes were also recovered in trees generated with the maximum-parsimony algorithm. Bootstrap values ( $>60 \%$ ) based on 1000 replications are shown at branch nodes. Bar, 0.005 substitutions per nucleotide position.

strain Gsoil $001^{\mathrm{T}}$ is $\mathrm{MK}-9\left(\mathrm{H}_{4}\right)$, which was consistent with the quinone system of the genus Kribbella. The presence of LL-diaminopimelic acid as the cell-wall peptidoglycan also supports the placement of the strain Gsoil $001^{\mathrm{T}}$ in the genus Kribbella. The fatty acid profile of strain Gsoil $001^{\mathrm{T}}$ comprised anteiso- $\mathrm{C}_{15: 0}(20.6 \%)$, iso- $\mathrm{C}_{16: 0}(11.5 \%)$, $\mathrm{C}_{16: 0}(8.8 \%), \mathrm{C}_{16: 0} 2-\mathrm{OH}(8.1 \%)$, iso- $\mathrm{C}_{15: 0}(6.4 \%)$, $\mathrm{C}_{18: 0}(6.3 \%)$, iso- $\mathrm{C}_{17: 0}(5.0 \%)$, ante- $\mathrm{C}_{18: 0}$ and/or $\mathrm{C}_{18: 2} \omega 6,9 c(3.9 \%)$, anteiso- $\mathrm{C}_{17: 0}(3.4 \%), \mathrm{C}_{16: 1} \omega 7 c$ and/ or iso- $\mathrm{C}_{15: 0} 2-\mathrm{OH}(3.3 \%)$, anteiso- $\mathrm{C}_{19: 0}(3.1 \%), \mathrm{C}_{18: 1} \omega 9 c$ $(2.9 \%), \mathrm{C}_{17: 1} \omega 8 c(2.9 \%)$, iso- $\mathrm{C}_{17: 1} \omega 9 c(2.8 \%), \mathrm{C}_{15: 0}$ (2.1\%), $\mathrm{C}_{18: 1} \omega 7 c / \omega 9 t / \omega 12 t$ (2.1\%), $\mathrm{C}_{20: 2} \omega 6,9 c$ (2.0\%), $\mathrm{C}_{10: 0}(1.8 \%)$ and $\mathrm{C}_{17: 0}(1.8 \%)$.

In summary, the characteristics of strain Gsoil $001^{\mathrm{T}}$ are consistent with the description of the genus Kribbella with regard to morphological, biochemical and chemotaxonomic properties. However, on the basis of the phylogenetic distances between strain Gsoil $001^{\mathrm{T}}$ and recognized Kribbella species, indicated by the $16 \mathrm{~S}$ rRNA gene sequence similarity values, and the combination of unique phenotypic characteristics (Table 1), it is demonstrable that strain Gsoil $001^{\mathrm{T}}$ should be assigned to the genus Kribbella in a novel species, for which the name Kribbella ginsengisoli sp. nov. is proposed.

\section{Description of Kribbella ginsengisoli sp. nov.}

Kribbella ginsengisoli (gin.sen.gi.so'li. N.L. n. ginsengum ginseng; L. n. solum soil; N.L. gen. n. ginsengisoli of soil of a ginseng field, the source of the type strain).

Gram-positive, strictly aerobic, non-spore-forming actinomycete. Extensively branched substrate mycelium penetrating into the agar and aerial mycelium are observed on R2A agar plates (Difco) and most media tested. Grows at $8-37{ }^{\circ} \mathrm{C}$ (no growth at 6 or $42{ }^{\circ} \mathrm{C}$ ) and pH 5.5-8.5. Growth occurs with up to $4.0 \%(\mathrm{w} / \mathrm{v}) \mathrm{NaCl}$. Grows on nutrient agar but not on MacConkey agar. Catalase- and oxidasepositive. Unable to reduce nitrate or nitrite under either aerobic or anaerobic conditions. Negative for production of $\beta$-galactosidase, arginine dihydrolase, lysine decarbox- ylase, ornithine decarboxylase, urease and tryptophan deaminase. Gelatinase- and Voges-Proskauer test-positive. Utilizes glucose as a sole carbon source but does not produce acid or gas from glucose. Indole is not produced from tryptophan; $\mathrm{H}_{2} \mathrm{~S}$ is not produced from sodium citrate. Degrades chitin, starch and casein, but not xylan, DNA or cellulose. The following compounds are utilized as sole carbon sources: $N$-acetylglucosamine, amygdalin, asparagine, aspartic acid, cellobiose, fructose, fumaric acid, gluconate, glutamic acid, glutamine, glycerol, glycogen, histidine, lactate, malate, melibiose, oxalic acid, phenylalanine, pyruvic acid, raffinose, sodium acetate, succinic acid, threonine, trehalose and valerate, but not adipate, adonitol, alanine, arginine, benzoic acid, caprate, cysteine, dextran, dulcitol, ethanol, formic acid, D-fucose, glutaric acid, glycine, 3- and 4-hydroxybenzoates, 3-hydroxybutyrate, inulin, isoleucine, itaconate, leucine, lysine, D-lyxose, maleic acid, malonate, methanol, methionine, phenyl acetate, proline, propionate, D-ribose, salicin, serine, sorbitol, L-sorbose, suberate, tartaric acid, tryptophan, tyrosine, valine or xylitol. Grows with antibiotic discs containing the following $(\mu \mathrm{g})$ : streptomycin sulfate $(2,4)$, gentamicin sulfate (2), tetracycline hydrochloride (4.5, $7.2)$, chloramphenicol $(5,10)$, kanamycin $(2,4)$, penicillin $(6,12)$ and erythromycin $(2,4)$; does not grow with streptomycin sulfate $(6,12)$, gentamicin sulfate $(4,6,12)$, tetracycline hydrochloride $(10,15)$, chloramphenicol (15, $30)$, kanamycin $(6,12)$, penicillin $(18,24)$ or erythromycin $(6,9)$. MK-9 $\left(\mathrm{H}_{4}\right)$ is the predominant menaquinone and anteiso- $\mathrm{C}_{15: 0}$ and iso- $\mathrm{C}_{16: 0}$ are the major cellular fatty acids $(>10 \%)$. The cell-wall peptidoglycan contains LLdiaminopimelic acid, glycine, alanine and glutamate. The polar lipids detected are diphosphatidylglycerol, phosphatidylcholine, phosphatidylglycerol and phosphatidylinositol. The cell-wall sugars detected are ribose, xylose and galactose. The DNA G $+\mathrm{C}$ content of the type strain is $66.3 \mathrm{~mol} \%$.

The type strain, Gsoil $001^{\mathrm{T}}$ (=KCTC $19134^{\mathrm{T}}=\mathrm{DSM}$ $17941^{\mathrm{T}}$ ), was isolated from the soil of a ginseng field in Pocheon Province, South Korea. 
Table 1. Physiological characteristics of strain Gsoil $001^{\top}$ and related type strains of the genus Kribbella

Strains: 1, K. ginsengisoli sp. nov. Gsoil $001^{\mathrm{T}}$ (data from this study); 2, K. yunnanensis DSM $15499^{\mathrm{T}}$ (Li et al., 2006); 3, K. alba DSM 15500 ${ }^{\mathrm{T}}$ (Li et al., 2006); 4, K. sandramycini KCTC $9609^{\mathrm{T}}$ (Park et al., 1999); 5, K. koreensis KACC 20250 ${ }^{\mathrm{T}}$ (Lee et al., 2000); 6, K. flavida KCTC 9580 ${ }^{\mathrm{T}}$ (Park et al., 1999); 7, K. antibiotica KCTC $19026^{\mathrm{T}}$ (Li et al., 2004); 8, K. swartbergensis DSM $17345^{\mathrm{T}}$ (Kirby et al., 2006); 9, K. karoonensis DSM 17344 ${ }^{\mathrm{T}}$ (Kirby et al., 2006); 10, K. lupini DSM $16683^{\mathrm{T}}$ (Trujillo et al., 2006); 11, K. solani KACC $20196^{\mathrm{T}}$ (Song et al., 2004); 12, K. jejuensis KACC 20266 ${ }^{\mathrm{T}}$ (Song et al., 2004); 13, K. hippodromi DSM $19227^{\mathrm{T}}$ (Everest \& Meyers, 2008); 14, K. aluminosa DSM $18824^{\mathrm{T}}$ (Carlsohn et al., 2007). All strains contained LLdiaminopimelic acid in the cell-wall peptidoglycan and could utilize sucrose as a sole carbon source. +, Positive; w, weakly positive; D, doubtful growth; -, negative; ND, no data available.

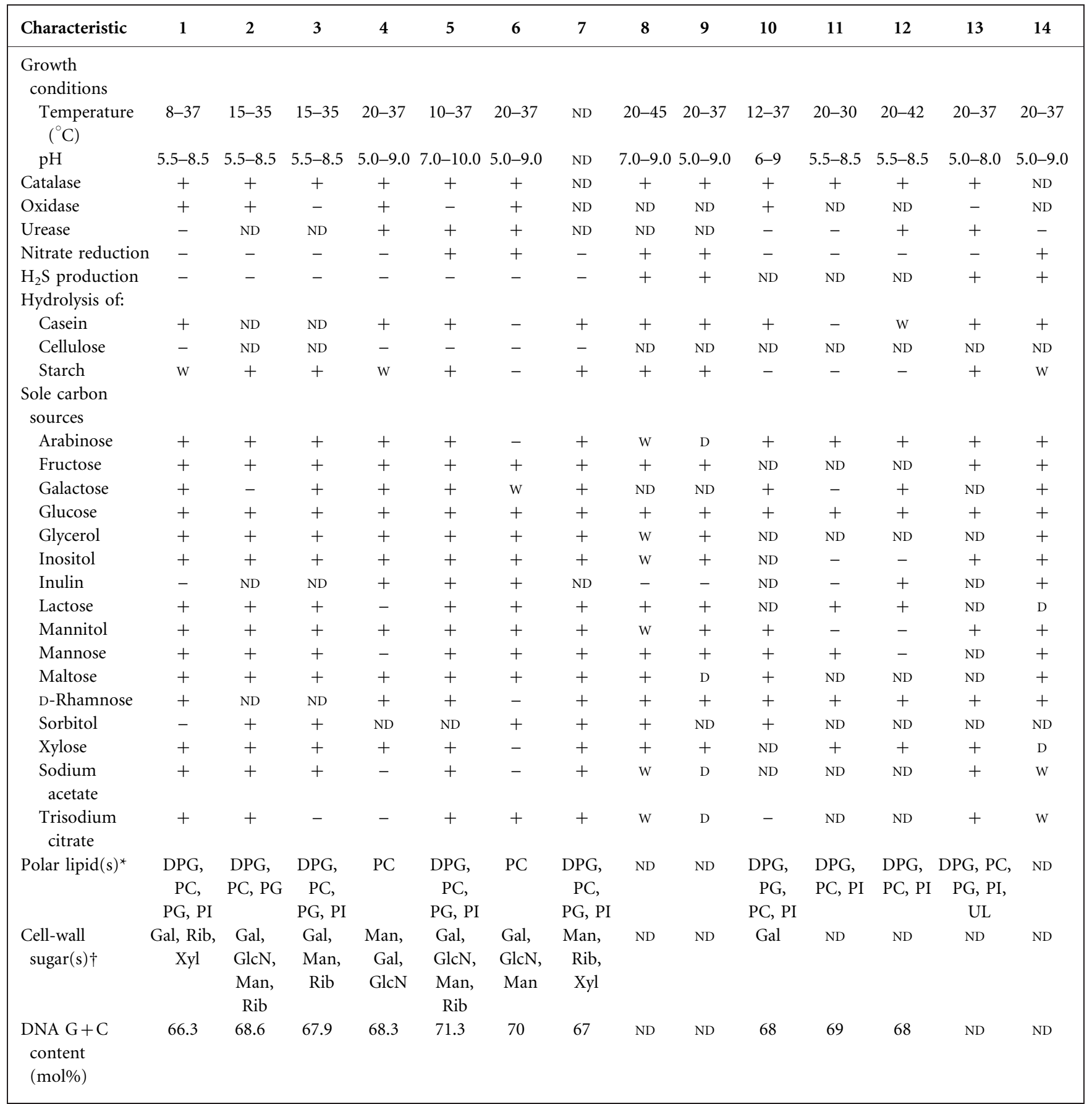

${ }^{\star}$ DPG, Diphosphatidylglycerol; PC, phosphatidylcholine; PG, phosphatidylglycerol; PI, phosphatidylinositol; UL, unknown lipids. $\dagger$ Gal, Galactose; GlcN, glucosamine; Man, mannose; Rib, ribose; Xyl, xylose. 


\section{Acknowledgements}

This work was supported by the 21C Frontier Microbial Genomics and Applications Center Program, Ministry of Education, Science \& Technology (grant MG08-0101-2-0) and a grant from the KRIBB Research Initiative Program of Republic of Korea.

\section{References}

Atlas, R. M. (1993). Handbook of Microbiological Media. Edited by L. C. Parks. Boca Raton, FL: CRC Press.

Buck, J. D. (1982). Nonstaining (KOH) method for determination of gram reactions of marine bacteria. Appl Environ Microbiol 44, 992993.

Carlsohn, M. R., Groth, I., Spröer, C., Schütze, B., Saluz, H.-P., Munder, T. \& Stackebrandt, E. (2007). Kribbella aluminosa sp. nov., isolated from a medieval alum slate mine. Int J Syst Evol Microbiol 57, 1943-1947.

Cui, Y.-S., Im, W.-T., Yin, C.-R., Lee, J.-S., Lee, K.-C. \& Lee, S.-T. (2007). Aeromicrobium panaciterrae sp. nov., isolated from soil of a ginseng field in South Korea. Int J Syst Evol Microbiol 57, 687-691.

Everest, G. J. \& Meyers, P. R. (2008). Kribbella hippodromi sp. nov., isolated from soil from a racecourse in South Africa. Int J Syst Evol Microbiol 58, 443-446.

Ezaki, T., Hashimoto, Y. \& Yabuuchi, E. (1989). Fluorometric deoxyribonucleic acid-deoxyribonucleic acid hybridization in microdilution wells as an alternative to membrane filter hybridization in which radioisotopes are used to determine genetic relatedness among bacterial strains. Int J Syst Bacteriol 39, 224-229.

Felsenstein, J. (1985). Confidence limits on phylogenies: an approach using the bootstrap. Evolution 39, 783-791.

Fitch, W. M. (1971). Toward defining the course of evolution: minimum change for a specific tree topology. Syst Zool 20, 406-416.

Hall, T. A. (1999). BioEdit: a user-friendly biological sequence alignment editor and analysis program for Windows 95/98/NT. Nucleic Acids Symp Ser 41, 95-98.

Hiraishi, A., Ueda, Y., Ishihara, J. \& Mori, T. (1996). Comparative lipoquinone analysis of influent sewage and activated sludge by highperformance liquid chromatography and photodiode array detection. J Gen Appl Microbiol 42, 457-469.

Kimura, M. (1983). The Neutral Theory of Molecular Evolution. Cambridge: Cambridge University Press.

Kirby, B. M., Roes, M. L. \& Meyers, P. R. (2006). Kribbella karoonensis sp. nov. and Kribbella swartbergensis sp. nov., isolated from soil from the Western Cape, South Africa. Int J Syst Evol Microbiol 56, 10971101.

Komagata, K. \& Suzuki, K. (1987). Lipid and cell-wall analysis in bacterial systematics. Methods Microbiol 19, 161-207.

Kouker, G. \& Jaeger, K.-E. (1987). Specific and sensitive plate assay for bacterial lipase. Appl Environ Microbiol 53, 211-213.

Kumar, S., Tamura, K. \& Nei, M. (2004). MEGA3: integrated software for molecular evolutionary genetics analysis and sequence alignment. Brief Bioinform 5, 150-163.

Lee, S.-D., Kang, S.-O. \& Hah, Y.-C. (2000). Hongia gen. nov., a new genus of the order Actinomycetales. Int J Syst Evol Microbiol 50, 191199.
Li, W.-J., Wang, D., Zhang, Y.-Q., Schumann, P., Stackebrandt, E., Xu, L.-H. \& Jiang, C.-L. (2004). Kribbella antibiotica sp. nov., a novel nocardioform actinomycete strain isolated from soil in Yunnan, China. Syst Appl Microbiol 27, 160-165.

Li, W.-J., Wang, D., Zhang, Y.-O., Xu, L.-H. \& Jiang, C.-L. (2006). Kribbella yunnanensis sp. nov., Kribbella alba sp. nov., two novel species of genus Kribbella isolated from soils in Yunnan, China. Syst Appl Microbiol 29, 29-35.

Mesbah, M., Premachandran, U. \& Whitman, W. B. (1989). Precise measurement of the $\mathrm{G}+\mathrm{C}$ content of deoxyribonucleic acid by highperformance liquid chromatography. Int J Syst Bacteriol 39, 159-167.

Minnikin, D. E., Patel, P. V., Alshamaony, L. \& Goodfellow, M. (1977). Polar lipid composition in the classification of Nocardia and related bacteria. Int J Syst Bacteriol 27, 104-117.

Moore, D. D. \& Dowhan, D. (1995). Preparation and analysis of DNA. In Current Protocols in Molecular Biology, pp. 2-11. Edited by F. W. Ausubel, R. Brent, R. E. Kingston, D. D. Moore, J. G. Seidman, J. A. Smith \& K. Struhl. New York: Wiley.

Park, Y.-H., Yoon, J.-H., Shin, Y.-K., Suzuki, K., Kubo, T., Seino, A., Kim, H.-J., Lee, J.-S. \& Lee, S.-T. (1999). Classification of 'Nocardioides fulvus' IFO 14399 and Nocardioides sp. ATCC 39419 in Kribbella gen. nov., as Kribbella flavida sp. nov. and Kribbella sandramycini sp. nov. Int J Syst Bacteriol 49, 743-752.

Saitou, N. \& Nei, M. (1987). The neighbor-joining method: a new method for reconstructing phylogenetic trees. Mol Biol Evol 4, 406425.

Sasser, M. (1990). Identification of bacteria by gas chromatography of cellular fatty acids, MIDI Technical Note 101. Newark, DE: MIDI Inc.

Sohn, K., Hong, S.-G., Bae, K.-S. \& Chun, J. (2003). Transfer of Hongia koreensis Lee et al. 2000 to the genus Kribbella Park et al. 1999 as Kribbella koreensis comb. nov. Int J Syst Evol Microbiol 53, 10051007.

Song, J., Kim, B.-Y., Hong, S.-B., Cho, H.-S., Sohn, K., Chun, J. \& Suh, J.-W. (2004). Kribbella solani sp. nov. and Kribbella jejuensis sp. nov., isolated from potato tuber and soil in Jeju, Korea. Int J Syst Evol Microbiol 54, 1345-1348.

Staneck, J. L. \& Roberts, G. D. (1974). Simplified approach to identification of aerobic actinomycetes by thin-layer chromatography. Appl Microbiol 28, 226-231.

Ten, L. N., Im, W.-T., Kim, M.-K., Kang, M.-S. \& Lee, S.-T. (2004). Development of a plate technique for screening of polysaccharidedegrading microorganisms by using a mixture of insoluble chromogenic substrates. J Microbiol Methods 56, 375-382.

Ten, L. N., Jung, H.-M., Yoo, S.-A., Im, W.-T. \& Lee, S.-T. (2008). Lysobacter daecheongensis sp. nov., isolated from sediment of stream near the Daechung dam in South Korea. J Microbiol 46, 519-524.

Thompson, J. D., Gibson, T. J., Plewniak, F., Jeanmougin, F. \& Higgins, D. G. (1997). The CLUSTAL_X windows interface: flexible strategies for multiple sequence alignment aided by quality analysis tools. Nucleic Acids Res 25, 4876-4882.

Trujillo, M. E., Kroppenstedt, R. M., Schumann, P. \& MartínezMolina, E. (2006). Kribbella lupini sp. nov., isolated from the roots of Lupinus angustifolius. Int J Syst Evol Microbiol 56, 407-411.

Wayne, L. G., Brenner, D. J., Colwell, R. R., Grimont, P. A. D., Kandler, O., Krichevsky, M. I., Moore, L. H., Moore, W. E. C., Murray, R. G. E. \& other authors (1987). International Committee on Systematic Bacteriology. Report of the ad hoc committee on reconciliation of approaches to bacterial systematics. Int J Syst Bacteriol 37, 463-464. 